\title{
MORPHOLOGICAL CHARACTERS OF THE FLOWERS AND THE STRUCTURE OF THE NECTARIES OF Acer platanoides L.
}

\author{
Elżbieta Weryszko-Chmielewska, Aneta Sulborska
}

\author{
Department of Botany, University of Life Science in Lublin, Akademicka 15, 20-950 Lublin, Poland \\ e-mail: elzbieta.weryszko@up.lublin.pl
}

Received: 05.05.2011

\begin{abstract}
The micromorphology of the nectaries and of other elements of the flower was examined by scanning electron microscopy (SEM). The anatomy of the nectaries was determined using light microscopy (LM). The inflorescences of $A$. platanoides comprise flowers included in two categories: functionally male and female. Nectaries of similar structure are found in both types of these flowers. The nectary gland located on the surface of the receptacle belongs to interstaminal nectaries. It has the form of a fleshy ring situated between the petals and the pistil. The bases of the staminal filaments are located in the depressions of the nectary. The outer diameter of the nectary reaches ca. $5 \mathrm{~mm}$, while the thickness of this gland's tissues is $400-700 \mu \mathrm{m}$. In the epidermis of the nectary gland, there are numerous, evenly distributed stomata through which nectar release occurs. The stomata function asynchronously. In some stomata, we could observe nectar drops flowing out and a layer of this secretion around the stomata. The secretory parenchyma of the nectary is composed of several layers of thick-walled cells, whereas the ends of the vascular bundles with xylem and phloem elements are situated in the subglandular parenchyma. Chloroplasts are found both in the epidermal cells and in the glandular parenchyma cells and photosynthesis can take place in them due to the nectary's good exposure to light. The presence of starch grains was found in the chloroplasts; they can be energy material for nectar production.
\end{abstract}

Key words: Acer platanoides, micromorphology of flowers, anatomy of nectary, epidermis, nectary parenchyma.

\section{INTRODUCTION}

Norway maple (Acer platanoides L.) blooms for the first time at the age of 20 (Maurizio and Graf 1, 1969). The flowers of this species form corymbs which develop before or simultaneously with leaves (K u g le r, 1970; S z w e y k ow s c y, 2003). The dish-shaped flowers of Acer, which produce nectar in abundance, are easily accessible to various groups of insects (K u g le r, 1970; Proct or et al. 1996).

The yellow-green sepals (5) and petals (5) reach a similar length. The flowers have a diameter of about $1 \mathrm{~cm}$ (S eneta and Dolatowski, 2007). The androecium consists of 8 stamens, with the basal part of the filaments embedded in the ring-shaped nectary disc. The pistil is composed of a two-chambered winged ovary and a style with two-lobbed stigma (Ma u rizio and Graf 1, 1969; Li pi ń ski, 2010). The flowers of this species are divided into several categories differing in stamen length and pistil size. According to various authors, unisexual functionally male flowers, with a small non-functional pistil, and functionally female flowers, with short stamens that do not mature, can be found in the inflorescences of A. platanoides (M a u r i z i o and G r a f 1, 1969; Tri p i ć, 2008). R e n n e r et al. (2007) report that monoecy with heterodichogamy belongs to sexual strategies in the flowering biology of this species.

Maurizio and Grafl (1969) report that the weight of nectar released by a single A. platanoides flower per day is $0.95 \mathrm{mg}$, with the average sugar content reaching $50 \%$. The secreted nectar forms large drops on the surface of the nectary. There are known light yellow coloured maple honeys with a delicate flavour and scent. Honey yield of this species is estimated at $1 \mathrm{~kg}$ per large tree (K o ł to w s k i, 2006), and a dense stand of $A$. platanoides trees is estimated at $200 \mathrm{~kg}$ per $1 \mathrm{ha}(\mathrm{J}$ a b ł oń s ki , 1989).

The aim of the present study was to determine some morphological characters of the perianth and generative elements as well as the micromorphology and anatomy of the nectary in the flowers of A. platanoides, since data on the structure of this gland are still very limited. 


\section{MATERIALS AND METHODS}

Acer platanoides $\mathrm{L}$. flowers were sampled from trees growing in different districts of the city of Lublin. The nectaries in fresh flowers were measured and photographed under a stereoscopic microscope equipped with a NIKON COOLPIX 4500 camera. Anatomical features of the nectaries were determined using a Nikon Eclipse 400 light microscope after hand-cut sections had been prepared from fresh material. Starch content in the nectary tissues was examined after the application of IKI solution. The presence of a cuticle on the epidermal surface of the nectary was tested using Sudan III solution.

For SEM examination, portions of flowers were fixed in $4 \%$ glutaraldehyde in $0.1 \mathrm{M}$ phosphate buffer at a $\mathrm{pH}$ of 7.0. Next, the plant samples were dehydrated in ethanol and acetone series and critical-point dried in liquid $\mathrm{CO}_{2}$. The sections were coated with gold using an EMITECH K550x sputter coater. The micromorphology of the nectaries and other floral elements was assessed under a TESCAN VEGA II LMU microscope.

\section{RESULTS}

\section{Morphological characters of the flowers}

Functionally male flowers (Figs 1C-E) and functionally female flowers (Figs 1F, 2A) develop in the inflorescences of Acer platanoides (Fig. 1A,B) at different times of the flowering period. They are produced in different numerical proportions in particular inflorescences. The diameter of these flowers collected from different trees ranged $12.5-16.5 \mathrm{~mm}$. The length of petals was on average $6.0 \mathrm{~mm}$, their width $2.5 \mathrm{~mm}$, while sepal length averaged $5.0 \mathrm{~mm}$. In functionally male flowers, the stamens reached an average length of $5.0 \mathrm{~mm}$, whereas the poorly developed pistil $1.0 \mathrm{~mm}$ (Fig. 1G). In functionally female flowers, the stamens were $2.0 \mathrm{~mm}$ long and the pistil reached a height of $5.5 \mathrm{~mm}$ (Fig. 1F).

The adaxial surface of the petals is covered with an epidermis producing short conical papillae (Fig. 2D). A striated cuticle can be seen on the surface of these cells. The mesophyll of the petals consists of branched spongy-parenchyma cells forming a tissue with a system of large intercellular spaces (Fig. 2F).

The short stamens in functionally female flowers produce pollen grains with very thick cell walls. The surface of a large flattened ovary of functionally female flowers is covered with glandular trichomes (Fig. 2A). In young flowers, these hairs are of unequal size and at different stages of development (Fig. 2E). Trichomes with heads composed of several up to several dozen cells can be observed among them (Figs $2 \mathrm{G}-$ J). Few stomata were also observed in the epidermis of the ovary (Fig. 2E). But no glandular hairs were found on the surface of the small ovary in functionally male flowers (Fig. 2B). Also, no glandular hairs were seen on the surface of developing fruits (Fig. 2B,C).

\section{The structure of the nectary}

The gland nectary of A. platanoides forms a fleshy ring located on the receptacle between the petals and the pistil (Figs 3A,B). In both types of flowers, the outer diameters of the slightly ellipsoidal nectary are similar and average $5.1 \times 4.6 \mathrm{~mm}$. The thickness of the nectariferous tissue is within a range of $400-700 \mu \mathrm{m}$. There are depressions in the places where the staminal filaments grow out in the nectary disc (Figs 3A-D), but the nectary tissues are not fused with the filaments.

The stomata are distributed evenly in the epidermis of the nectary (Figs 3D, 4A), and the guard cells are located in different directions. A stoma complex is surrounded 6-8 epidermal cells (Figs 3E, 4B, 6F). During nectar secretion, the stomata are raised above other epidermal cells (Fig. 3F, 4E, 6B-D), whereas after the end of this process both the stomata and the epidermal cells surrounding them slightly subside (Fig. 4C). In the guard cells, there are chloroplasts in which starch grains form; it is revealed when the tissues are treated with IKI solution (Fig. 6F).

The stomata on the nectary surface function asynchronously. In addition to stomata surrounded by a layer of secreted nectar, there were also observed some stomata through which the nectar had not been secreted yet (Fig. 3F). A layer of secreted nectar was observed around the pores both under a scanning microscope (Figs 4C-E) and a light microscope (Fig. 6E). Drops of secreted nectar containing granular structures (Fig. 6G-I) could be observed using light microscopy in the pores of some stomata. SEM observations reveal that drying nectar can form spherical structures of different size (Fig. 4B, E).

Large, flattened epidermal cells with slightly convex outer walls can be distinguished in vertical section of the nectary (Fig. 5A-C). The walls of these cells are relatively thin and covered with a layer of smooth or finely striated cuticle (Fig. 4B, 5C). The epidermal cells are poorly vacuolized (Fig. 5C) and contain chloroplasts (Figs 6B, E).

The nectary's parenchymal cells with a thick cytoplasm form a dark streak in vertical section of the gland (Fig. 6A). The glandular parenchyma is composed of 8-10 layers of cells with smaller dimensions and thicker walls than those observed in the cells of the subglandular parenchyma layers (Figs 5A; 6B,E). The subepidermal glandular layer consists of tightly packed cells resembling palisade parenchyma (Figs 5B; 6B,E). The tangential walls of these cells are strongly thickened, likewise in the tangential collenchyma cells. Large cell nuclei and chloroplasts occur in the glandular parenchyma cells. The vascular bundles running to the stamens and the perianth segments branch out and xylem and phloem elements reach the subglandular layer (Fig. 6A). 

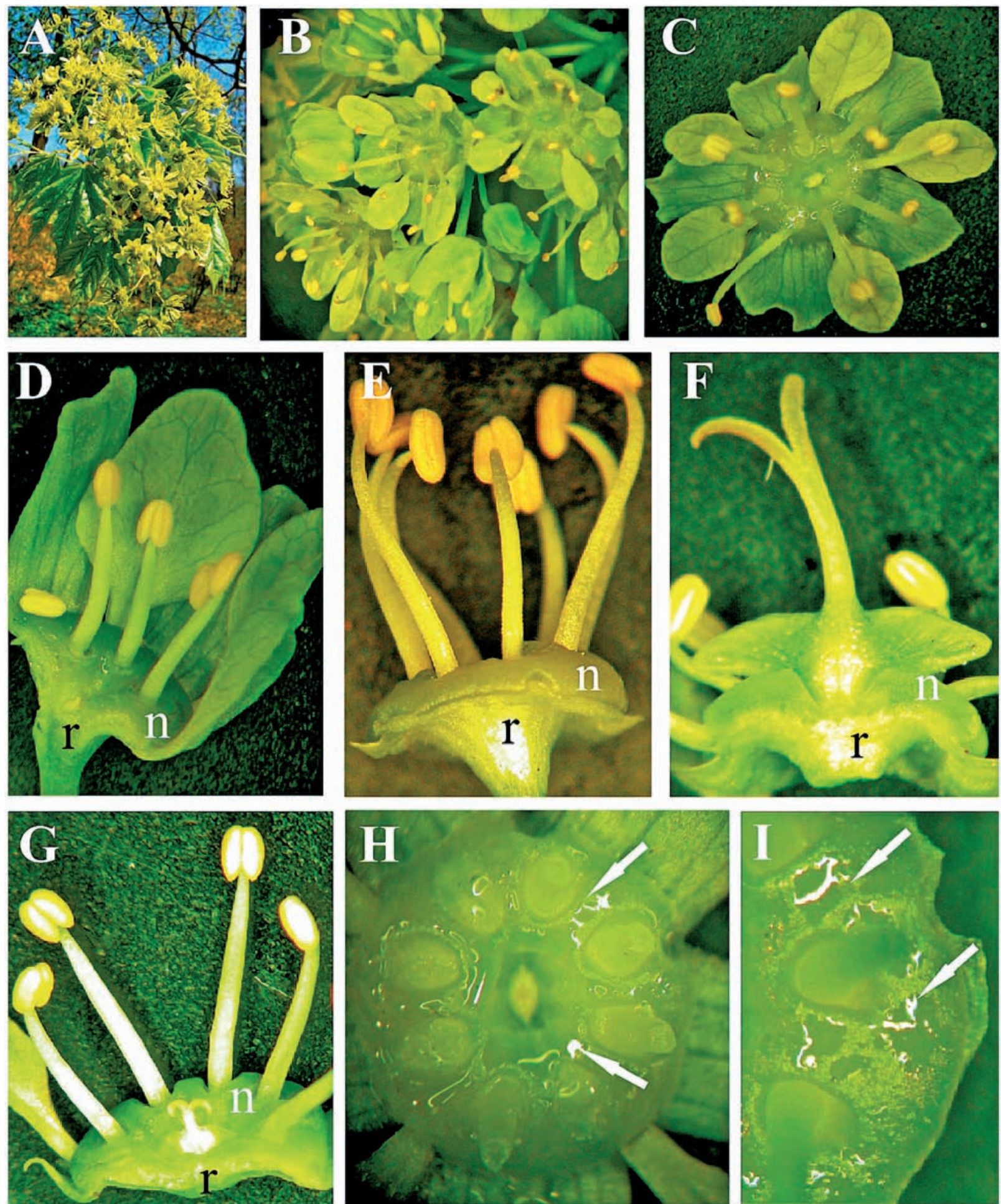

Fig. 1. Nectaries in the morphologically and functionally differentiated flowers of Acer platanoides.

A, B - Inflorescences; C - functionally male flower; D,E - nectaries in functionally male flowers; F - vertical sectional view of a functionally female flower; $\mathrm{G}$ - portion of a functionally male flower with the nectary; H,I - layer of nectar on the nectary surface; $\mathrm{n}$ - nectary, $\mathrm{r}$ - receptacle.

A-x 0.5; B-x 2; C-x 4; D-x 7;, E-x 8; F,G - x 9; H-x 12; I -x 17. 

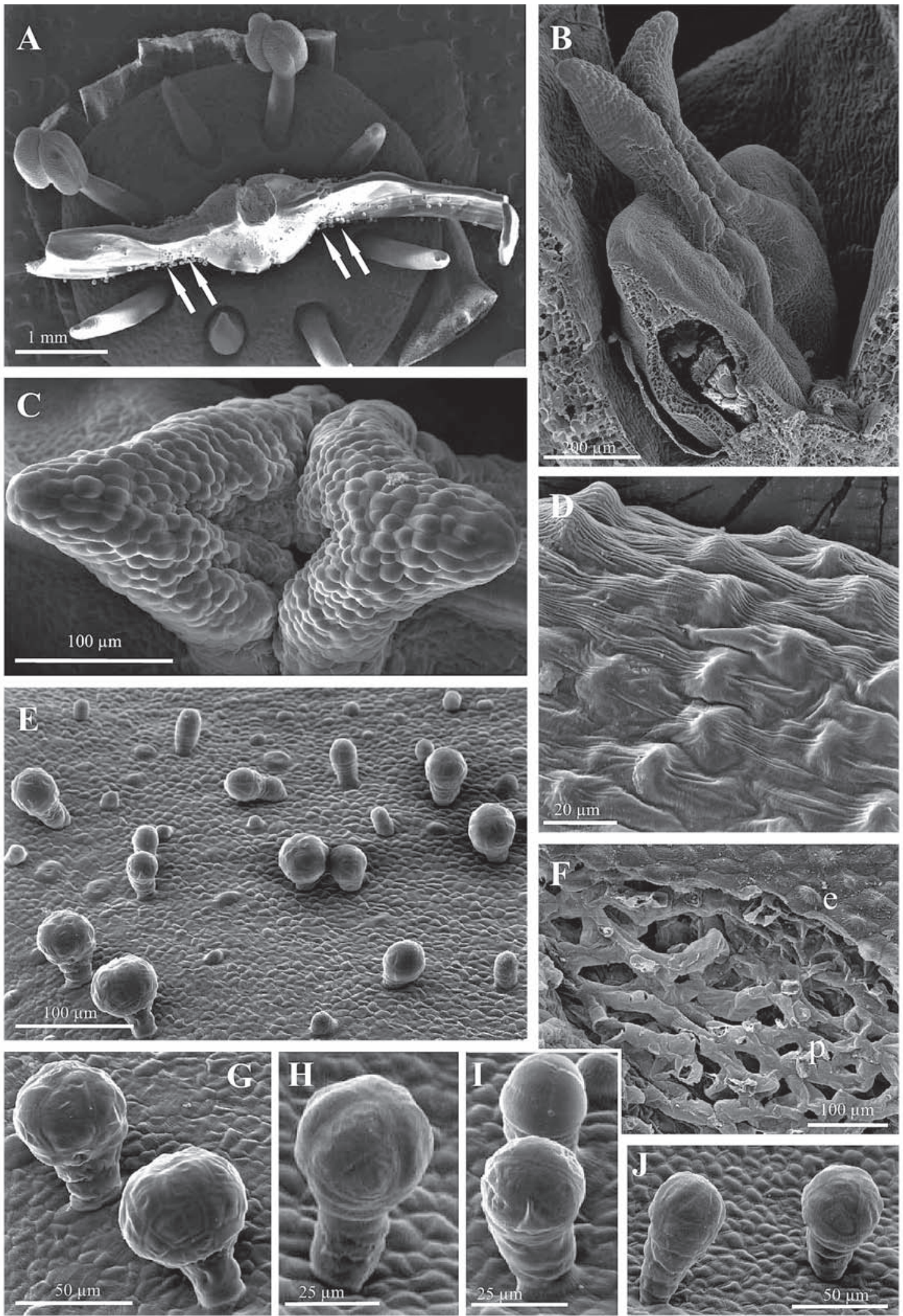

Fig. 2. Portions of A. platanoides flowers (SEM).

A - Glandular trichomes (arrows) on the surface of the pistil's ovary in a functionally female flower; B - pistil from a functionally male flower; $\mathrm{C}$ - two-lobbed stigma of the pistil from Fig. B; D - papillae in the adaxial epidermis cells of a petal; E - different-sized glandular trichomes from the ovary surface; F - sectional view of a petal with the epidermis (e) and spongy parenchyma (p); G-J - glandular trichomes with different-sized heads from the ovary surface. 

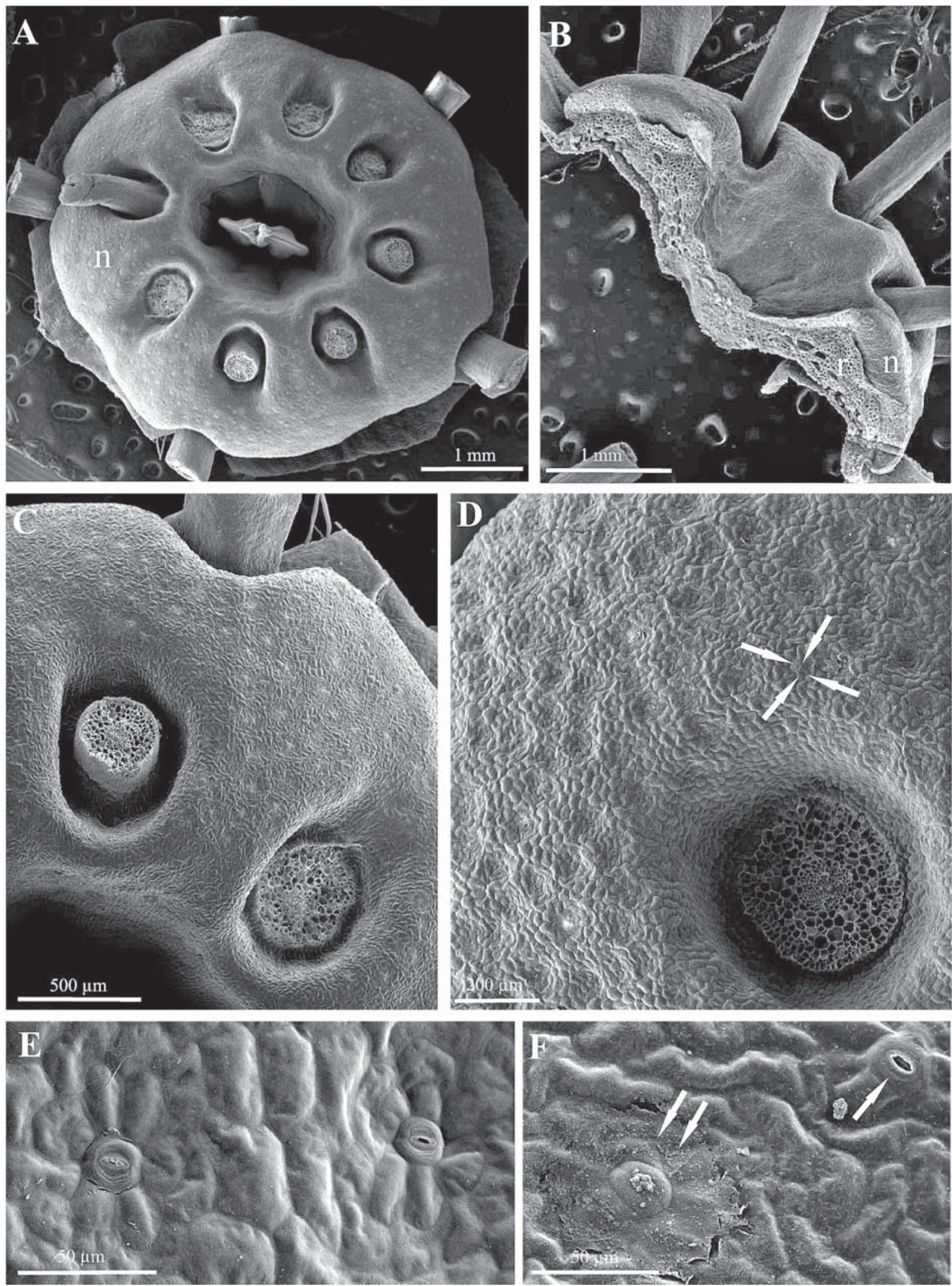

Fig. 3. Micromorphology of the nectaries in A. platanoides (SEM).

A - Nectary (n) viewed from above after the stamens and perianth segments were cut off; B - vertical sectional view of the receptacle (r) with the nectary (n); C,D - surface portions of the nectary with depressions visible by the filaments and numerous stomata (arrows); E - stomata in the epidermis of the nectary before nectar secretion; $\mathrm{F}$ - stoma during nectar secretion (double arrows) and before nectar secretion (arrow). 

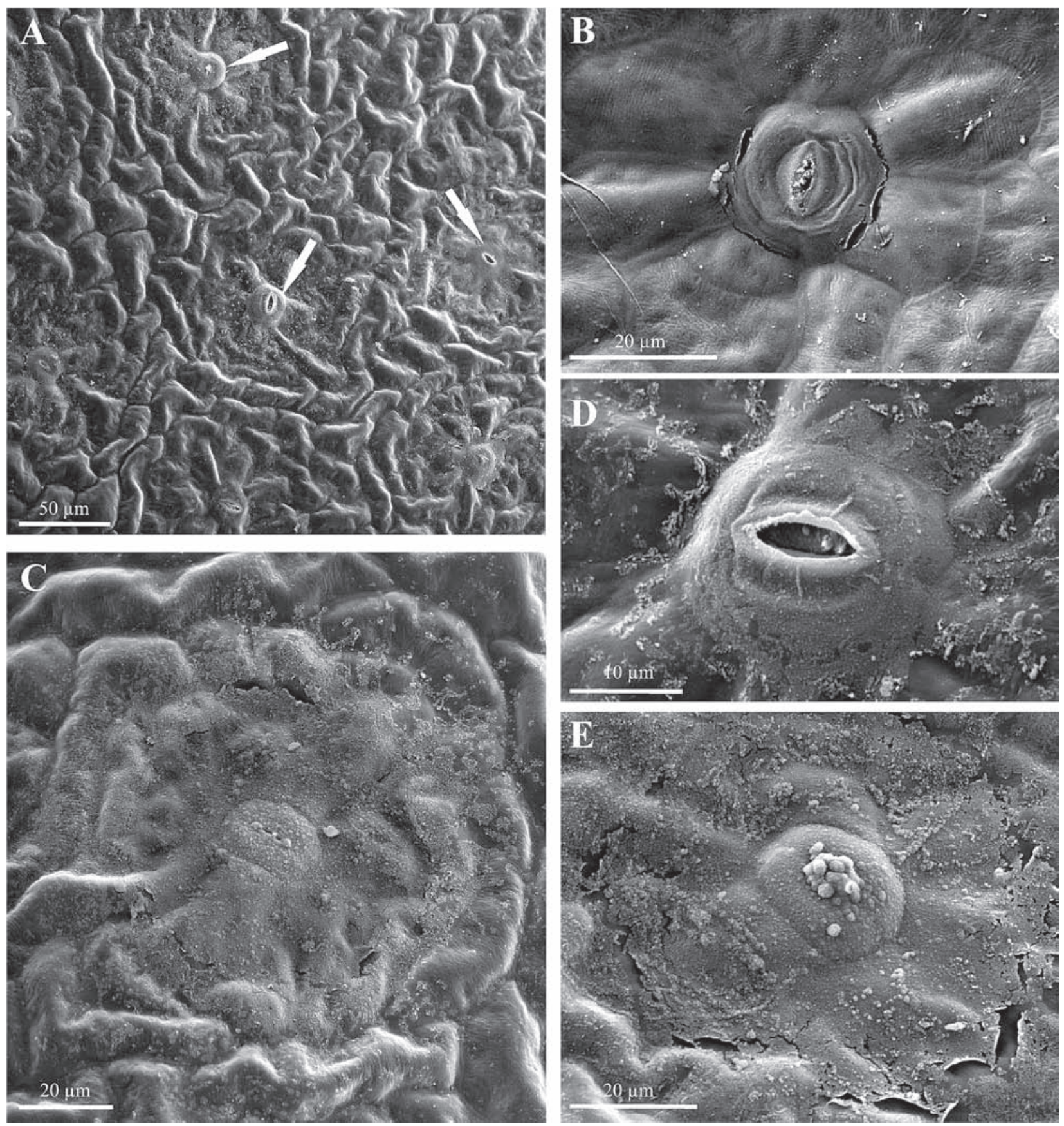

Fig. 4. Surface portions of the nectary in A. platanoides (SEM).

A - Stomata evenly distributed around the epidermal cells with convex outer walls; B - stoma at the beginning of nectar secretion; C,D,E -stomata during nectar secretion with visible granular structures in the pores and a layer of dried nectar on the surface of the epidermal cells. 

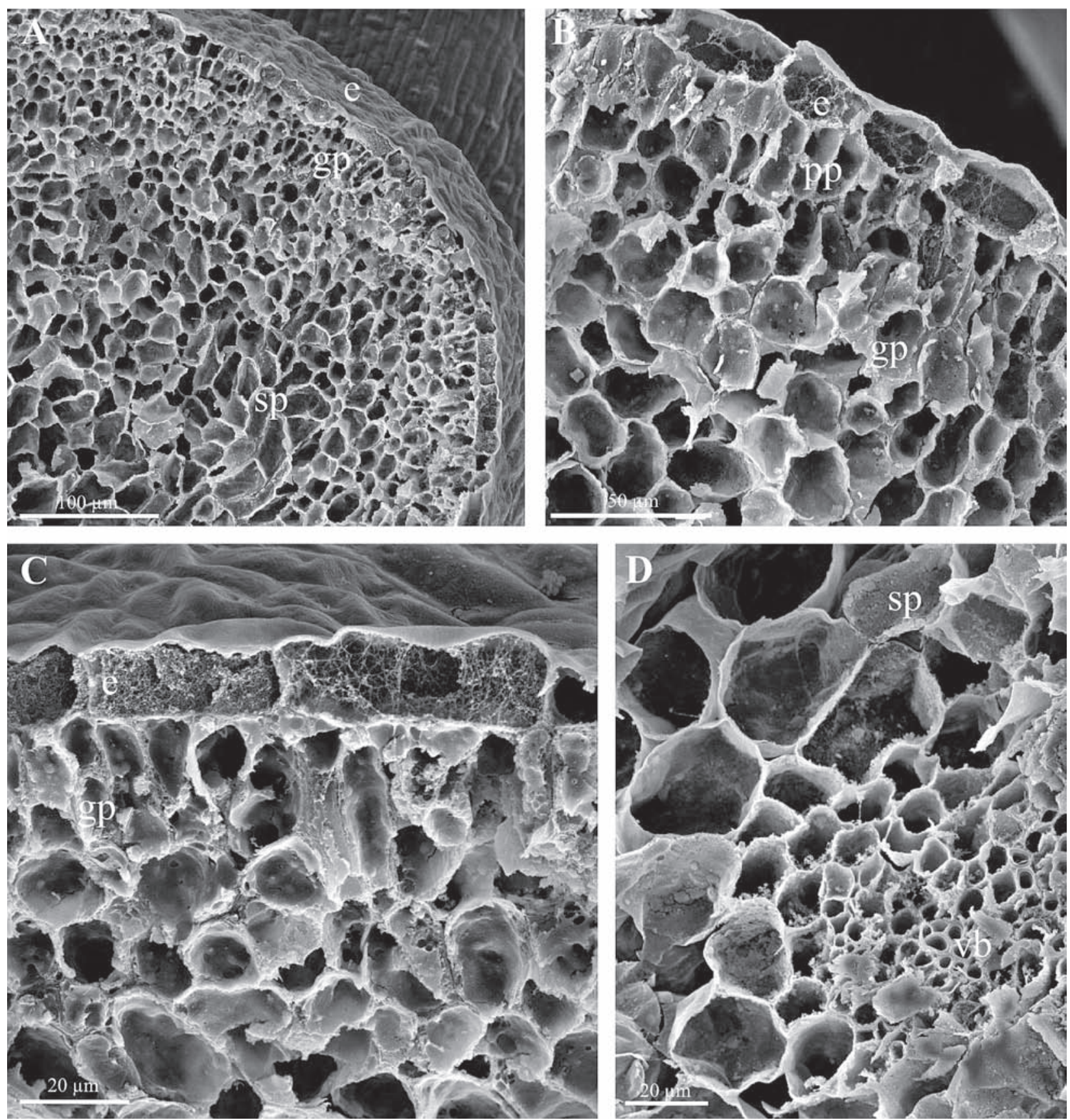

Fig. 5. Vertical sections of the nectary in A. platanoides (SEM).

A - Nectary tissues: e - epidermis, gp - glandular parenchyma; sp - subglandular parenchyma; B - epidermal cells (e); subepidermal layer of cells similar to palisade parenchyma (pp); layers of glandular parenchyma (gp); C - poorly vacuolized epidermal cells (e) and tightly packed glandular parenchyma cells (gp); D - vascular bundle (vb) in the layer of subglandular parenchyma (sp). 
$\mathbf{A}$
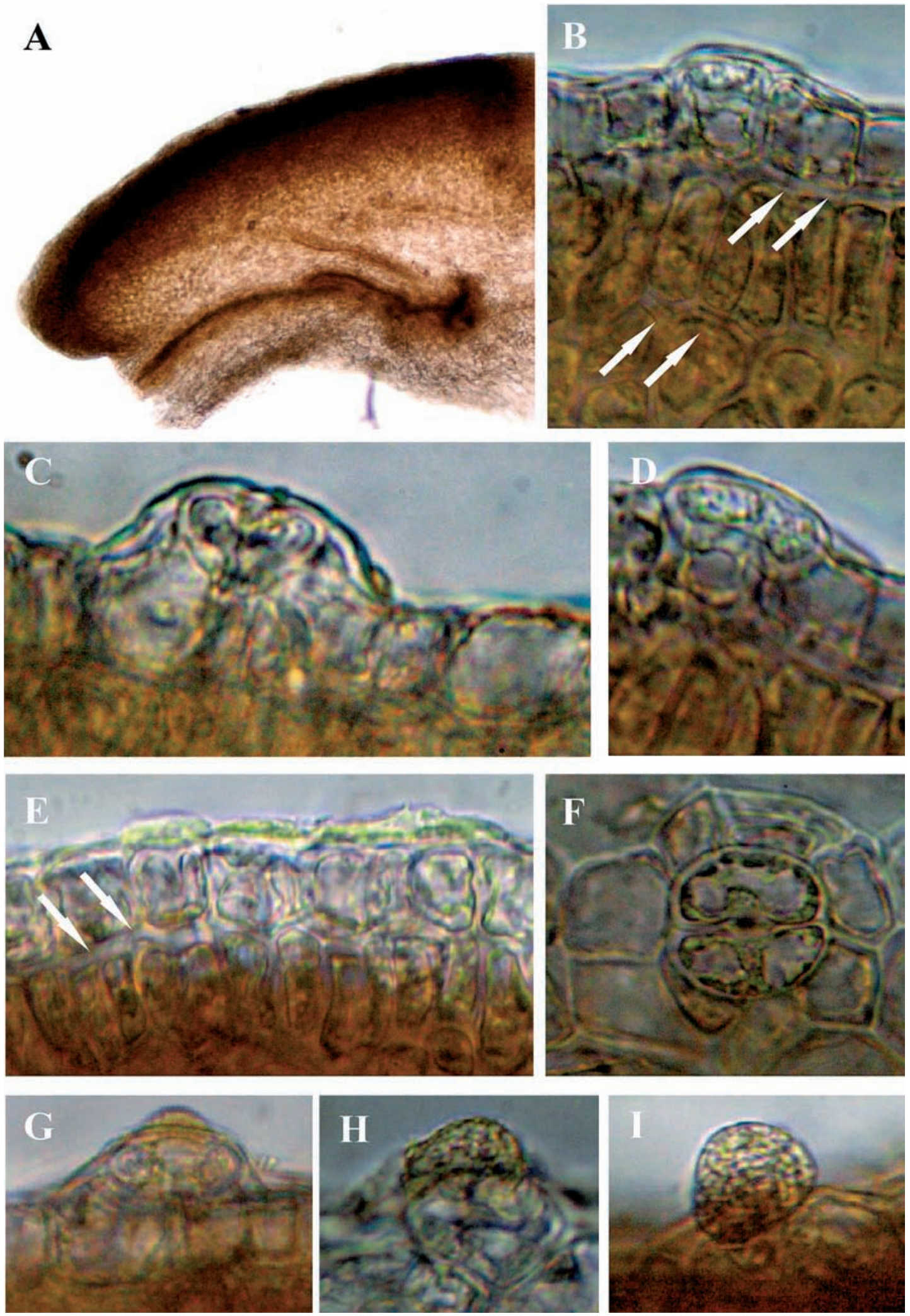

Fig. 6. Vertical sections of the nectary in A. platanoides (LM).

A - Nectary tissues with a dark-stained layer of glandular parenchyma and a brighter subglandular layer in which the vascular bundles run; B,C,D - stomata raised above the surface of other epidermal cells, thick cell walls (arrows) are visible in the glandular parenchyma cells; E - layer of greenish nectar on the epidermis surface as well as thickened inner walls of the epidermis and glandular parenchyma (arrows); F - stoma viewed from above; G,H,I - stomata with drops of nectar being released. A - x 50; B-I - x 1000 . 


\section{DISCUSSION}

The nectary gland located in the dish-shaped flowers of Acer platanoides belongs to receptacular nectaries. 3 types are distinguished within receptacular nectaries, depending on their location in relation to stamens: extrastaminal, intrastaminal, and interstaminal (S c h mid, 1988; B e rn a rd e 11 o, 2007). The nectary of Acer located between the stamens represents the interstaminal type. Nectaries of the above-mentioned type also occur in representatives of the order Celastrales (M a t th ew s and Endre s s, 2005); this order is closely related to the order Sapindales to which the family Aceraceae belongs.

Our study shows that the diameter of the slightly ellipsoidal nectary of $A$. platanoides reaches $5.1 \times 4.6 \mathrm{~mm}$. But Li piński (2010) reports that it is $3.5 \mathrm{~mm}$. The numerous stomata through which nectar is secreted are distributed regularly on the surface of the nectary of A. platanoides. H a r a g s i m (1977) also reports that in maple nectar is secreted unto the nectary surface through the stomata. Our observations demonstrate that the stomata in the nectaries of Acer platanoides function asynchronously. We observed similar asynchronous functioning of the nectarostomata in Elaeagnus commutata ( $\mathrm{C} \mathrm{h} \mathrm{w} \mathrm{i} 1$ and $\mathrm{W}$ e r y s z k o- Ch mi e lew s k a, 2011). Apart from that, we found the occurrence of closed nectarostomata during anthesis as well as before and after nectar secretion. This may be evidence that in Acer platanoides the pores regulate to some degree the flowing out of nectar. It has been found in other plant species that modified stomata of nectaries are not able to closely regulate nectar secretion (Davis and Gunning, 1993; Razem and D a v is , 1999; Nepi, 2007).

The nectar-secreting stomata in A. platanoides are much raised above the surface of the epidermis, contrary to the stomata that did not secret nectar. Our observations are in agreement with the data given by Gaffal et al. (1998), Nepi et al. (1996) as well as Weryszko-Chmielewska and Chwil $(2005,2007)$ who found a similar situation in the nectaries of other plant species.

The nectary tissues observed in the present study were supplied by the branches of the vascular bundles reaching the stamens and the perianth segments. According to Maurizio and Grafl (1969), only phloem branches reach the nectary tissues in this species.

The yellow-green nectaries located in the flowers of A. platanoides are directly exposed to light. We found that chloroplasts occurred both in the epidermal cells and in the parenchymal cells of the nectary. Our observations also show that cells of the above-mentioned tissues can provide for nectar production carbohydrates produced as a result of photosynthesis.
$\mathrm{Ne} \mathrm{pi} \mathrm{(2007)} \mathrm{reports} \mathrm{that} \mathrm{the} \mathrm{walls} \mathrm{of} \mathrm{the} \mathrm{nec-}$ tary's parenchyma are usually thin. In A. platanoides, we observed in the subepidermal layer of parenchyma thick tangential walls resembling tangential collenchyma walls. Collenchymatic cells with strongly thickened walls in this layer were observed by S t p i c z y ń s k a et al. (2003) in Maxillaria and S t p i c z y ń s ka et al. (2009) in Ornithidium (Orchidaceae).

Secondary nectar presentation to pollinators is found in the flowers of many plant species and perianth segments play a major role in it ( $\mathrm{Pacini}$, Nepi, Vesprini, 2003). On the other hand, primary presentation occurs in open flowers of A. platanoides when nectar is offered to insects from the nectary surface.

\section{REFERENCES}

B ernarde11o G., 2007. A systematic survey of floral nectaries. [In:] S.W. Nicolson, M. Nepi, E. Pacini, (eds), Nectaries and Nectar. Springer, Dordrecht.

Chwil M., Weryszko-Chmielewska E., 2011. Micromorphology of the floral elements, the structure of the nectary, and the apicultural value of Elaeagnus commutata Bernh. Ex Rydb. Acta Agrobot. 64 (1): 27-34.

Davis A.R., Gunning B.E.S., 1993. The modified stomata of the floral nectary of Vicia faba L. III. Physiological aspects, including comparison with foliar stomata. Botanica Acta, 106: 241-253.

Gaffal K.P., Heimler W., El-Gammal S., 1998. The floral nectary of Digitalis purpurea L., structure and nectar secretion. Ann. Bot. 81: 251-262.

Harags im O., 1977. The nectar secretion of maple (Acer platanoides L.) and sycamore (A. pseudoplatanus L.). Apidologie, 8 (4): 363-368.

Jabłoński B ., 1989. Rozdziały z botaniki pszczelarskiej. / Chapters on apicultural botany. [In:] J. Marcinkowski (ed.) Terminarz pszczelarski, Powszechne Wydawnictwo Rolnicze i Leśne, Warszawa.(in Polish)

Kugler H.G., 1970. Blütenökologie. Veb Gustav Fischer Verlag, Jena (in German).

Kołtowski Z., 2006. Wielki atlas roślin miododajnych. Przedsiębiorstwo Wydawnicze Rzeczpospolita SA, Warszawa.(in Polish)

Lipiński M., 2010. Pożytki pszczele. Zapylanie i miododajność roślin. Powszechne Wydawnictwo Rolnicze i Leśne, Warszawa; Wydawnictwo Sądecki Bartnik, Stróże. (in Polish)

Matthews M.L., Endress P.K., 2005. Comparative floral structure and systematics in Celastrales (Celastraceae, Parnassiaceae, Lepidobotryaceae). Bot. J. Linn. Soc. 149: 129-194.

Maurizio A., Grafl I., 1969. Das Trachtpflanzenbuch. Ehrenwirth Verlag, München (in German).

Nepi M., 2007. Nectary structure and ultrastructure. [In:] S.W. Nicolson, M. Nepi, E. Pacini (eds), Nectaries and nectar. Springer, Dordrecht. 
Nepi M., Ciampolini F., Pacini E., 1996. Development and ultrastructure of Cucurbita pepo nectaries of male flowers. Ann. Bot. 81: 251-262.

Pacini E., Nepi M. Vesprini J.L., 2003. Nectarbiodiversity: a short review. Plant Syst. Evol. 238: 7-21.

Proctor M., Yeo P., Lack A., 1996. The natural history of pollination. Harper Collins, London.

Razem F.A., Davis A.R., 1999. Anatomical and ultrastructural changes of the floral nectary of Pisum sativum L. during flower development. Protoplasma, 206: 57-72.

Renner S.S., Beenken L., Grimm G.W., Kocyan A., Ricklefs R.E., 2007. The evolution of dioecy, heterodichogamy, and labile sex expression in Acer. Evolution, 61: 2701-2719.

S ch mid R., 1988. Reproductive versus extra - reproductive nectaries - historical perspective and terminological recomendations. Bot. Rev. 54: 179-232.

Seneta W., Dolatowski J., 2007. Dendrologia. Wydawnictwo Naukowe PWN, Warszawa. (in Polish)

Stpiczyńska M., Davies K.L., Gregg A., 2003. Nectary structure and nectar secretion in Maxillaria coccinea (Jacq.) L.O. Williams ex Hodge (Orchidaceae). Ann. Bot. 93: 87-95.

Stpiczyńska M., Davies K.L., Gregg A., 2009. Nectary structure of Ornithidium sophronitis Rchb. f. (Orchidaceae: Maxillariinae). Acta Agrobot. 62 (2): 3-12.

Szweykowscy A. J., 2003. Słownik botaniczny. Państwowe Wydawnictwo Wiedza Powszechna, Warszawa (in Polish).

Tripić R., 2008. Contribution to the knowledge of flowering phenology and sex expression in Acer platanoides L. from Montenegro. Natura Montenegrina, Podgorica, 8 (1): 11-22.

Weryszko-Chmielewska E., Chwil M., 2005. Morphological features of the nectary and of the pollen grains and the foraging value of the flower sof yellow azalia (Rododendron luteum Sweet.). J. Apic. Sci. 49 (2): 5-12.

Weryszko-Chmielewska E., Chwil M., 2007. Micromorphology of the epidermis of the floral nectary of Rododendron japonicum (A. Gray), J.V. Suringar ex E.H. Wilson. Acta Agrobot. 60 (1): 45-53.

\section{Cechy morfologiczne kwiatów i struktura nektarników Acer platanoides L.}

\author{
Streszczenie
}

Struktura nektarników kwiatowych Acer platanoides nie została dotychczas wystarczająco poznana. Mikromorfologię nektarników i innych elementów kwiatu badano przy użyciu skaningowego mikroskopu elektronowego (SEM). Anatomię nektarników określono w mikroskopie świetlnym (LM). W kwiatostanach A. platanoides występują kwiaty zaliczane do dwóch kategorii: funkcjonalnie męskie i żeńskie. W obu typach kwiatów występują nektarniki o podobnej budowie. Gruczoł nektarnikowy położony na powierzchni dna kwiatowego należy do nektarników interstaminalnych. Ma postać mięsistego pierścienia położonego między płatkami a słupkiem. Nasady nitek pręcikowych znajdują się w obrębie zagłębień nektarnika. Zewnętrzna średnica nektarnika osiąga ok. $5 \mathrm{~mm}$, a grubość tkanek gruczołu 400-700 $\mu \mathrm{m}$.

W epidermie gruczołu nektarnikowego występują liczne, równomiernie rozmieszczone aparaty szparkowe, przez które odbywa się uwalnianie nektaru. Aparaty szparkowe funkcjonują niesynchronicznie. W niektórych szparkach obserwowano wypływające krople nektaru, a wokół nich warstwę tej wydzieliny. Parenchymę wydzielniczą nektarnika tworzy kilka warstw grubościennych komórek, natomiast w parenchymie podgruczołowej są widoczne zakończenia wiązek przewodzących. Zarówno w komórkach epidermy, jak też w komórkach parenchymy gruczołowej występują chloroplasty, w których może się odbywać proces fotosyntezy ze względu na dobrą ekspozycję nektarnika na światło. W chloroplastach stwierdzono obecność ziaren skrobi, które mogą stanowić materiał energetyczny do produkcji nektaru. 